\title{
WHY THE MILITARY FORCES? THE ROLE AND CAPABILITIES OF MILITARY FORCES IN THE PROTECTION AGAINST DISASTERS
}

\author{
Júlia HORNYACSEK \\ National University of Public Service, Budapest, Hungary \\ hornyacsek.julia@uni-nke.hu
}

\begin{abstract}
The events of recent times have proven that disasters have become part of our lives. The greatest danger is caused by the damage to and the destruction of the built environment, which makes the population vulnerable. Nowadays, in order to provide effective actions against disasters, complex disaster management systems have evolved throughout Europe, and protection has become an all-society task. Military forces of a given country are also involved in this task. The question arises what kind of damages are caused to the built environment by disasters, how the elimination of damages is resolved and what role the reformed military forces may have in it.

In this article, the author has set out to analyze the characteristics of incident sites created by disasters, identifying their impacts on the built environment, as well as the tasks or capabilities needed to perform these tasks. In the light of this, she investigates if military organizations, through their basic function, have all the capabilities that, without special improvements, can make them capable of effectively contributing to the provision of rescue tasks.
\end{abstract}

KEYWORDS: disaster, incident site, rescue activities, military forces, defense/protection capabilities

\section{Introduction}

According to the disaster statistics of United Nation Office for Disaster Risk Reudction (UNISDR), a total damage of USD $1.4 \mathrm{~T}$ was caused by disasters in the world between 2005 and 2014, with 0.7 million people killed and 1.7 billion people affected (EM-DAT, 2016).

These figures encourage states to develop an advanced and complex disaster management system, but the attention of scientific researchers is also directed to the subject. As a result of scientific researches, the literature of the analysis of disasters is rich and shows the organizations, and the investigation their capabilities, whose basic functions are the elimination of disasters, such as the fire service or civil protection, or where there is an institutionalized form already established, disaster management as well (Hornyacsek, 2011; Bonnyai, 2014; Bundesamt für Bevölkerungsschutz, 2015; Antal, 2017; Muhoray, 2017; Tóth \& Siposné, 2017; Varga, 2017).

However, the number of writings is fewer that "only" investigate organizations 
involved in disaster management and their role in eradicating damages, like the military forces. Scientific forums and news report in more and more cases that to eliminate disasters of large scale or affecting large masses, cannot be imagined without the involvement of military forces. The involvement of military organizations during disasters was analyzed by researchers in the past mostly in a particular field (e.g., applicability of aircraft, water purification capabilities, etc.) and not in relation to requirements or capabilities (Kiss, 2015; Szabó \& Tóth, 2015).

In the protection against disasters, there is a need for more and more involvement of the military forces, so, it is important to also examine if in our region, with the disappearance of the bipolar world order, after personnel and resource reductions in connection with the reform of the forces, are military organizations capable of performing the emerging tasks.

Nowadays, with the change in the security environment, states have arrived at the following step of the reform of military forces, therefore, the research related to the topic can create a good foundation for decision-makers in the development of future military forces. The research tasks and requirements related to military forces and disasters may bring results that would make it even more pronounced to the specialists and decision-makers that the maintenance of the capabilities needed for the involvement by military forces in disaster management would also be important in the future. In order to be able to analyze the possible role of military forces in disaster management, we need to look at the contexts of disasters and security, and the damages to the built environment caused by them, later, also the tasks related to the elimination of the damages. The basis for this was provided by one of my earlier studies, when I investigated 41 disaster incidents and the analysis of the rescue operations (Hornyacsek, 2017, p. 34), in which I identified the features of the damages and the tasks to be done. In the framework of this study, I assigned to them the demand for personnel and assets. In the light of all this, it becomes possible to compare the necessary capabilities and requirements with the capabilities of military organizations.

\section{Disasters and Security}

Disasters and the protection against them have nowadays become a security policy factor, so, the countries in the region have included disasters in their security strategies, and name them as factors threatening the safety and security of their countries and citizens and their properties (Magyarország Kormánya, 2012, p. 34; SWP \&GMF, 2013; p. 39; The Presidential Administration Romania, 2015, pp. 16, 64). Disaster statistics nowadays divert our attention to other interesting phenomena. Table no. 1 shows the damages due to disasters between 2012 and 2015, the number of the affected and killed people. While the value of damages is decreasing, the number of the affected people shows a similar value, however, the number of people killed shows a three-fold increase.

Table no. 1

Disasters in numbers, 2012-2015 (edited by the author, references: Disasters in... 2015)

\begin{tabular}{|c|c|c|c|}
\hline & Damage (USD M) & People affected (M) & People killed \\
\hline 2015 & 66.5 & 98.6 & 22,773 \\
\hline 2014 & 110 & 102 & 7,000 \\
\hline 2013 & 119 & 96 & 21,110 \\
\hline 2012 & 156 & 107 & 11,154 \\
\hline
\end{tabular}


Much of the deaths occur between the occurrence of an incident and the arrival of the rescue forces to start their first response. Therefore, it is important that the defense/ protection system responds fast and efficiently. In the countries of our region, risk assessment was introduced with regard to disasters, and the states elaborated the so-called Country Reports to give account of the vulnerabilities and the measures taken to identify the risks, which is based on the given country's disaster management (Cabinet Office, 2012; MSB, 2012; Magyarország Kormánya, 2014; Norwegian Directorate for Civil Protection, 2014; GIES, 2016). Building a protection system, developing its capabilities takes place in the light of the risks and the expected tasks. Organizations should engage in the implementation of tasks such as military organizations which, in terms of their capabilities, meet the requirements. Tasks depend on damages and on the incident sites emerging, therefore, I examine the consequences of disasters and the impacts they may have.

\section{The Impact of Disasters on the} Built Environment and the Damage to Its Main Elements

News related to major disasters of recent years has reported that thousands of people had died or remained without cover because residential buildings collapsed, became uninhabitable, and roads and utilities broke down. In most cases, complex, complicated incident sites were created that make it difficult to quickly start and execute rescue tasks. Because of the content constraints, my research studies of the impacts of disasters are only presented in this article regarding the built environment; it does not cover the social impacts or the damages to the natural environment.

Built environment can be devastated by not only natural or industrial disasters, but also by negligent or deliberate human activities. Industrial and technical development often coincides with the danger of the occurrence of disasters as well. For any reason a disaster has occurred (earthquakes, floods, storms, extreme weather, global warming, fires, explosions, etc.), one should count with the complex, combined impacts on the built environment. These impacts are as follows:

- in low-lying areas, the occurrence of floods and inland waters, in higher areas, the emergence of flash floods and their devastating effects (rockslides, landslides, etc.);

- contamination of rivers, water intakes, water reservoirs and other water basins by toxic substances;

- spill of petroleum products and other aggressive (toxic) substances, liquids damaging the environment;

- industrial facilities, warehouses, shops, residential and public buildings may be damaged or collapsed, causing housing and supply problems;

- the occurrence of fires, the formation of overlapping areas under fire;

- the destruction, damage, and the inaccessibility of roads, bridges, underpasses and overpasses, utilities, as a result of which power supply and utilities can stop and other transport and transport problems may arise;

- the injury or inoperability of IT and communication systems;

- the formation of coherent rubble and debris surfaces that hinder the access to the incident sites and to carry out rescue tasks;

- the injury, death or health impairment of humans and animals.

On the incident sites, due to disasters, buildings, roads, bridges, railways, public utilities, power supply and communication systems, rivers, dams, reservoirs and other waterworks and structures can also be damaged. Let us examine their features. 
Features of the destruction of and damage to buildings and building structures

In the built environment, buildings (residential and public buildings), building structures (industrial facilities, warehouses, etc.) are most exposed to the devastating effects of disasters. Earthquakes, explosions, floods, fires and tsunamis cause the greatest devastation, resulting in the supports and wall structures losing their strength, partially or completely, thus destroying the buildings (strong, moderate and moderate destruction), the various structures being damaged (deformation, damage, partial or full collapse) as well as losing their static stability (displacement, sinking, tilting, rolling).

Due to destructions caused by explosions, coherent ruins develop on roads and buildings. Due to the soaking effect of floods, the soil structure loosens, which can also make it difficult (or obstruct) the execution of rescue tasks. Fire nodes often occur as a result of electric or gas pipeline injuries, and due to water pipeline breaches, watercourses may create mudslides at the bottom of the ruins, causing the deaths of those stranded there.

Features of damages to roads, bridges, railways, traffic structures and junctions

The damage to and the disruption of road networks and adjoining structures (underpasses, overpasses, tunnels, etc.), providing surface transportation are basically caused by earthquakes, tsunamis, flash floods and the soaking effects of floods and inland waters. The foundation of roads exposed to such impacts lose their strengths or continuity, therefore, the road surface breaks, becomes fragmented or sinks. Roads may sink or break and will be unsuitable for traffic. Also, mud avalanches or rock slides may ruin roads or their structural elements due to various reasons. It should also be noted that public utilities that have been placed under or near roads are also damaged. Tunnels and underground crossings, their wall structures may become damaged and ruptured, and their use may become impossible due the infiltrating subsurface waters. Overpasses and structures providing offset, multi-level traffic, due to the damage to their supporting structures, lose their bearing capacity or static stability, either partially or fully, therefore, one or more structural elements may break, their foundation may crash or completely collapse. Due to disasters, in particular as a result of earthquakes, explosions or highly destructive floods, bridges may be damaged. Depending on the type and design, pillar structures, the main load bearers of the support structure, the structures of the various brackets or tensioners, their elements, and the track structure of bridges may be damaged. It is necessary to count with transport and traffic problems or the changes of the flow conditions of rivers, deteriorating shipping conditions. If under the track structures of bridges public utilities are laid, they are also expected to collapse together with the damage to bridge structures, so, rescue forces must be prepared to restore them as well. In the case of tracked surface transport systems (railways, tramway and suburban railways, etc.), disasters most often disrupt track structures and safety equipment, and power supply networks (top cables and their accessories, electrical cables, etc.). Rail tracks may break, deform, the stability of railway levees may cease, and one must be prepared to face how the structural elements of railway overpasses, switches, stations, platforms, loading points and electrical overhead lines, and their supporting structures may break. In the case of underground transport systems, already in the planning phase (subway, underground railways, etc.), taking into account the expected, significant disaster effects, their stability is better than the one of other transport systems. Nonetheless, it may happen that the structural elements of 
tunnels or their related structures may be damaged due to building defects, or due to greater disaster loads or for other reasons. In such cases, water leaks, water bursts may happen, utilities and energy networks in the tunnel may become inoperable. Due to the damage to the power grids, one may count with fires or traffic jams, causing passengers be trapped in the tunnels.

Features of damages to utilities, power supply and communication systems

Public utilities, because of their underground location, are most exposed to the effects of earthquakes and floods. As a result of earth movements, public tunnels and shafts may collapse, public utilities can deform, break, and pipe joints may be damaged or loosened. The injury or inoperability of automated signaling systems, shut-off valves, pumping stations and booster stations, may pose a particular source of danger.

Due to the damage to water pipeline networks, the heavily draining water may destroy road surfaces and buildings, and inundates the deep-lying areas, floods cellars, tunnels and underpasses. It dampens the soil and surface structure, which may sink, collapse. The damage to shut-off fittings prevents the blocking or disabling of defective systems.

Due to the damage to and the disruption of the sewage network and sewage treatment plants, the surrounding areas may become contaminated, which ma infiltrate into the nearby rivers and the groundwater. Surface and underground pipes may deform, break and crumble, and clog the structures. Due to the failure of pumping stations, one should count with waste water damaging streets, squares, residential and public buildings.

Distance heating pipelines run either over or under the surface, due to their injury one should count with the outflow of high temperature steam and hot water. The outflowing high-temperature fluid may endanger the environment, the nearby buildings and may make it difficult to repair them.
Amongst public utilities, the damage to the gas supply networks means the greatest danger to the environment and rescue activities. If a pipeline is broken and one fails to shut it down shortly, a large amount of gas can be spilled into the atmosphere, which may cause fire or explosions while damaging the health. Ruptures of pipelines, besides the damages to couplings or shut-off valves, the breakdown of booster stations and equipment as well as control systems may cause problems.

The damage to the electricity power supply networks, in a physical sense, does not trigger a dangerous situation as the previous ones, because it is not accompanied by environmental damages or destruction. However, due to its widespread use, a multi-day power outage may cause a serious problem for the population. Disasters and extraordinary weather usually cause line breaks, as well as damaging transformer stations or pylons.

Communication systems play an important role in the lives of people, but in a physical sense they are not always a part of the built environment of a particular settlement, because the location of the ground facilities and equipment are determined by the satellite or mobile phone operators. In the case of disasters, basically the repeater stations and their facilities, equipment, antennas and repeaters are destroyed.

Features of damages to rivers, dams, reservoirs, waterworks and structures

As a result of the impacts of different disasters, the water level of rivers and creeks may rise, water can inundate lowlying areas, damaging the shores, dams, waterworks, and residential buildings, public buildings, public utilities and industrial facilities.

It may happen that the reservoirs of settlements may become damaged, as well as the water intake sites may get contaminated. The vast amount of water destroyed buildings, utilities, and floods 
low-lying areas. The flood carries on the dangerous substances that may harm the health, and may contaminate the water intake of a settlement as well. The latter, even in the long run, may cause problems in the life of a settlement.

\section{The Rescue and Rehabilitation}

Tasks, the Personnel and Asset Requirements of Disaster Incident Sites of the Built Environment

In the above, I have examined what damages disasters may can cause to the built environment, now, I determine the tasks to be carried out in order to prevent damages and escalation. Normally, complex damages are generated in the built environment and complex incident sites are created. In this case, the primary goal is to prevent the spread of disasters and to save as many human lives as possible. Rescuers, in addition to engineering tasks, are faced with public health and disinfection (decontamination) tasks, related to the lifesaving, as well as the protection of the rescuers and the provision of operating conditions. The tasks to be performed and the resources are sorted and summarized in the following table:

Table no. 2

Damages-tasks-personnel and asset requirements (edited by the author)

\begin{tabular}{|c|c|c|c|}
\hline \multicolumn{2}{|c|}{ Types of damages } & Basic tasks & $\begin{array}{l}\text { Personnel and asset } \\
\text { requirements }\end{array}$ \\
\hline \multirow{4}{*}{ 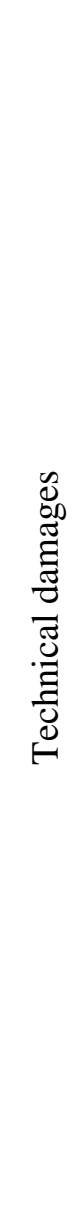 } & $\begin{array}{l}\text { Damage to the } \\
\text { public works }\end{array}$ & $\begin{array}{l}\text { closure of utilities, exploration of } \\
\text { injuries, sectioning, firefighting, repair, } \\
\text { troubleshooting, restorative earthworks }\end{array}$ & $\begin{array}{l}\text { specialists, earthwork, } \\
\text { transport and loading } \\
\text { machines, repair tools, } \\
\text { materials, hand tools, etc. }\end{array}$ \\
\hline & $\begin{array}{l}\text { Damage to } \\
\text { industrial plants, } \\
\text { agricultural } \\
\text { establishments }\end{array}$ & $\begin{array}{l}\text { removing ruins from roads, savior of } \\
\text { machinery, raw materials, livestock, } \\
\text { fodder; exploration and repair of } \\
\text { damages to buildings, cleansing of the } \\
\text { soil, restarting production }\end{array}$ & $\begin{array}{l}\text { specialists, conveyor, loading } \\
\text { and unloading heavy } \\
\text { machinery, watering machines, } \\
\text { dismantling and cutting tools, } \\
\text { grapples, graders, fire trucks, } \\
\text { building and decontamination } \\
\text { materials }\end{array}$ \\
\hline & $\begin{array}{l}\text { Damage to } \\
\text { residential and } \\
\text { public buildings }\end{array}$ & $\begin{array}{l}\text { removing ruins from roads, } \\
\text { extinguishing fires, reinforcing or } \\
\text { dismantling damaged building } \\
\text { structures, rescuing the injured, } \\
\text { temporary accommodation of the } \\
\text { population, partial or complete } \\
\text { reconstruction of buildings, disinfecting } \\
\text { or decontaminating the area }\end{array}$ & $\begin{array}{l}\text { specialists, conveyor, loading } \\
\text { and unloading heavy } \\
\text { machinery, watering machines, } \\
\text { dismantling and cutting tools, } \\
\text { grapples, graders, hoists, } \\
\text { hoists, cranes, hand tools }\end{array}$ \\
\hline & $\begin{array}{l}\text { Damage to and } \\
\text { disruption of } \\
\text { transport } \\
\text { systems }\end{array}$ & $\begin{array}{l}\text { the removal of ruins, exploration, repair } \\
\text { of roads, railways, traffic structures, the } \\
\text { injuries to utilities; reconstruction and } \\
\text { earthworks, providing the re-launch } \\
\text { conditions for transport systems }\end{array}$ & $\begin{array}{l}\text { specialists, earthwork } \\
\text { machines, road, bridge and } \\
\text { railroad construction machines, } \\
\text { conveyor and loading } \\
\text { machines, cranes, demolition } \\
\text { and cutting tools excavating } \\
\text { and gripping machines, hand } \\
\text { tools, tractors, construction } \\
\text { materials }\end{array}$ \\
\hline
\end{tabular}




\begin{tabular}{|c|c|c|c|}
\hline \multicolumn{2}{|c|}{ Types of damages } & \multirow{2}{*}{$\begin{array}{l}\text { Basic tasks } \\
\text { cleansing of access roads, exploring the } \\
\text { damages, restoring the supporting } \\
\text { structures of lines; repairing of structures } \\
\text { and equipment, providing temporary } \\
\text { energy supply, creating conditions for a } \\
\text { smooth service }\end{array}$} & \multirow{2}{*}{$\begin{array}{l}\text { Personnel and asset } \\
\text { requirements } \\
\text { specialists, earthwork } \\
\text { machines, aggregators, } \\
\text { transport and loading } \\
\text { machines, cranes, excavators } \\
\text { and grippers, tractor cutters, } \\
\text { construction materials, hand } \\
\text { tools, repair tools, materials, } \\
\text { etc. }\end{array}$} \\
\hline 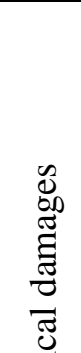 & $\begin{array}{l}\text { Damage to } \\
\text { energy supply } \\
\text { and } \\
\text { commutation } \\
\text { systems }\end{array}$ & & \\
\hline 总 & $\begin{array}{l}\text { Damage to } \\
\text { rivers and } \\
\text { reservoirs }\end{array}$ & $\begin{array}{l}\text { construction and cleansing of access } \\
\text { roads, saving injured animals, re- } \\
\text { enforcing dykes and shorelines, } \\
\text { cleansing the water intake, disinfecting } \\
\text { the area, water and sediment } \\
\text { decontamination }\end{array}$ & $\begin{array}{l}\text { specialists, floating vehicles, } \\
\text { earthmoving machines, } \\
\text { irrigation trucks, transport and } \\
\text { loading tools, grapples, cranes, } \\
\text { tractors, hand tools, pumps, } \\
\text { building materials, etc. }\end{array}$ \\
\hline \multirow{3}{*}{ 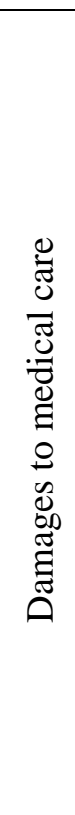 } & $\begin{array}{l}\text { Human injuries } \\
\text { and deaths, } \\
\text { deaths of } \\
\text { animals }\end{array}$ & $\begin{array}{l}\text { rescuing people and animals from the } \\
\text { incident sites; setting up temporary } \\
\text { health care facilities, triage, care and } \\
\text { accommodation of the injured }\end{array}$ & $\begin{array}{l}\text { ambulances, casualty transport } \\
\text { vehicles, sanitary } \\
\text { decontamination, } \\
\text { accommodation, supply assets, } \\
\text { materials, tents, sprinklers and } \\
\text { transport vehicles, etc. }\end{array}$ \\
\hline & $\begin{array}{l}\text { Emergence of } \\
\text { infections and } \\
\text { epidemics }\end{array}$ & $\begin{array}{l}\text { detection and elimination of infection } \\
\text { nodes; establishment of quarantine } \\
\text { zones, localization and decontamination } \\
\text { of the infected areas }\end{array}$ & $\begin{array}{l}\text { casualty transport vehicles, } \\
\text { supply and medical devices, } \\
\text { disinfectants and medicines, } \\
\text { watering and transport } \\
\text { vehicles, etc. }\end{array}$ \\
\hline & $\begin{array}{l}\text { Overload of } \\
\text { hospitals, } \\
\text { medical support } \\
\text { problems }\end{array}$ & $\begin{array}{l}\text { setting up emergency hospitals, } \\
\text { rehabilitating damaged clinics, } \\
\text { increasing patient support and } \\
\text { transportation capabilities, creating } \\
\text { conditions for normal operating order } \\
\text { and recovery }\end{array}$ & $\begin{array}{l}\text { health, accommodation, supply } \\
\text { materials, equipment, casualty } \\
\text { transport vehicles, tents, } \\
\text { backup energy sources, } \\
\text { construction equipment and } \\
\text { materials, etc. }\end{array}$ \\
\hline \multirow{2}{*}{ 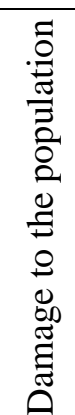 } & $\begin{array}{l}\text { Supply } \\
\text { problems }\end{array}$ & $\begin{array}{l}\text { supplying the population with drinking } \\
\text { water, food and clothing }\end{array}$ & $\begin{array}{l}\text { warm and long-shelf-life food } \\
\text { storage sets, cooking } \\
\text { equipment, clothing materials, } \\
\text { pure drinking water, water } \\
\text { purification capability; }\end{array}$ \\
\hline & $\begin{array}{l}\text { Accommodation } \\
\text { problems }\end{array}$ & $\begin{array}{l}\text { temporary accommodation, restructuring } \\
\text { of buildings, setting up emergency } \\
\text { camps, providing hygiene conditions }\end{array}$ & $\begin{array}{l}\text { beds and cots, tents, emergency } \\
\text { and living containers, building } \\
\text { materials and tools }\end{array}$ \\
\hline
\end{tabular}

It can also be seen from the table that the tasks are extremely diverse, require personnel and assets. No organization can handle them alone, however, based on the principle of cost-effectiveness, it is expedient to involve organizations in performing the tasks that have the most capabilities and strengths listed in the table above. In most countries, military forces are best suited for this. I will examine it below. 
5. The Relationship between the Capabilities of Military Organizations and the Requirements of Disaster Management

Disaster management tasks are carried out primarily by organizations, whose basic function is to eliminate the consequences of disasters (fire service, civil protection, and in several countries, there are professional disaster management organizations as well), but as a contributor, public administration has a role to play (defense/protection administration, NGOs and charity organizations, and law enforcement and military forces as well.

Military forces in most countries of Europe have a great tradition of fighting disasters. "The Hungarian military forces through their capabilities contribute to responding to natural and industrial disasters, to eliminate their consequences, to manage humanitarian emergencies, to support the evacuation of those forced to leave their homes, to assist displaced people in Hungary and abroad as well" (Padányi \& Halász; 2012, p. 180).

In addition to general military tasks, the Romanian armed forces also perform other special and disaster management tasks such as "...to support national and local public authorities in emergencies, to provide assistance to the population, and to provide disaster and technological accidents relief" (MoND, 2015). It is similar in other Central European countries as well. In Austria, civilians having completed their military service and active soldiers are also involved in disaster management, being able to work in extreme conditions. Soldiers constitute the "Island of stability" (Soldaten als "Inseln der Stabilität”), expressed by Brigadier Mag. Erich Cibulka - Head of Plattform Wehrhaftes Österreich, on the role of military servicemen (Wehrhaftes, 2017). What demonstrates that military organizations are best suited in a society to participate, along with disaster management organizations, in performing such tasks?

To prove it, one should compare the requirements against rescue forces participating in disaster response and the capabilities of military organizations in this relation.

Table no. 3

Requirements against rescue forces and the capabilities of military forces (edited by the author)

\begin{tabular}{|l|l|l|}
\hline & Requirements against rescue forces & Capabilities of military forces \\
\hline 1. & $\begin{array}{l}\text { Rescue forces must have a rapid alert system, be } \\
\text { able to be deployed, in a short time, in any area of } \\
\text { the country }\end{array}$ & $\begin{array}{l}\text { They have a separate alarm system, they } \\
\text { can be deployed anywhere in the country } \\
\text { in a short time }\end{array}$ \\
\hline 2. & $\begin{array}{l}\text { Rescue forces must have an efficient command and } \\
\text { control and communication system }\end{array}$ & $\begin{array}{l}\text { Military organizations have state-of-the- } \\
\text { art command, communication and } \\
\text { reporting systems. }\end{array}$ \\
\hline 3. & $\begin{array}{l}\text { The personnel must be professionally prepared for } \\
\text { and capable of cooperating with other organizational } \\
\text { units. }\end{array}$ & $\begin{array}{l}\text { The professional preparation training of } \\
\text { the personnel is continuous and there is a } \\
\text { need to cooperate with other } \\
\text { organizational units. }\end{array}$ \\
\hline 4. & $\begin{array}{l}\text { They should be able to carry out their tasks } \\
\text { independently, have the means, labor safety and } \\
\text { equipment to carry out their job. }\end{array}$ & $\begin{array}{l}\text { They have the means, the material and } \\
\text { technical conditions required to carry out } \\
\text { their tasks independently. }\end{array}$ \\
\hline 5. & $\begin{array}{l}\text { Understand the operation of their equipment, be able } \\
\text { to use them properly and effectively, as required. }\end{array}$ & $\begin{array}{l}\text { The personnel is trained to operate their } \\
\text { equipment and they are required to } \\
\text { efficiently use them. }\end{array}$ \\
\hline
\end{tabular}




\begin{tabular}{|c|c|c|}
\hline & Requirements against rescue forces & Capabilities of military forces \\
\hline 6. & $\begin{array}{l}\text { Have equipment, wheeled and tracked excavators to } \\
\text { remove roadblocks, to open gateways, to scourge } \\
\text { and dismantle buildings. }\end{array}$ & $\begin{array}{l}\text { They have equipment, wheeled and } \\
\text { tracked earthwork machines, for all tasks } \\
\text { in a ruined area. }\end{array}$ \\
\hline 7. & $\begin{array}{l}\text { Have earthwork machines that are suitable for } \\
\text { performing earthwork and flood response activities. }\end{array}$ & $\begin{array}{l}\text { Earth-moving machines of engineering } \\
\text { units are suitable for construction and } \\
\text { flood response purposes. }\end{array}$ \\
\hline 8. & $\begin{array}{l}\text { Have high-performance road, water, rail transport } \\
\text { vehicles and loading machines, with own or hired air } \\
\text { transport capacity. }\end{array}$ & $\begin{array}{l}\text { The army has the technical means and } \\
\text { the necessary loading machines for all } \\
\text { kinds of transportation. }\end{array}$ \\
\hline 9. & $\begin{array}{l}\text { Have reconnaissance vehicles and special equipment } \\
\text { for aerial and ground reconnaissance. Be able to } \\
\text { correctly evaluate data, provide accurate information } \\
\text { for leadership decisions. }\end{array}$ & $\begin{array}{l}\text { The army has trained recce personnel, } \\
\text { aerial and ground recce devices, which } \\
\text { and who are capable of correctly } \\
\text { processing data and delivering reliable } \\
\text { information. }\end{array}$ \\
\hline 10. & $\begin{array}{l}\text { Have fast floating vehicles, suitable for heavy loads } \\
\text { and with diving capabilities. }\end{array}$ & $\begin{array}{l}\text { Engineering, river and maritime units } \\
\text { have their own transport and diving } \\
\text { capabilities. }\end{array}$ \\
\hline 11. & $\begin{array}{l}\text { Have the personnel trained to build temporary roads, } \\
\text { bridges; machines and equipment necessary to } \\
\text { perform their job. }\end{array}$ & $\begin{array}{l}\text { The personnel of engineering units are } \\
\text { capable of building and repairing roads, } \\
\text { bridges, utilities and buildings, have } \\
\text { machines and tools needed for this. }\end{array}$ \\
\hline 12. & $\begin{array}{l}\text { Be able to work in a contaminated work area, have } \\
\text { adequate protective equipment and equipment for } \\
\text { decontamination. }\end{array}$ & $\begin{array}{l}\text { The personnel of military organizations } \\
\text { are trained to work in radiation and } \\
\text { chemical contaminated areas, have } \\
\text { protective equipment and tools. }\end{array}$ \\
\hline 13. & $\begin{array}{l}\text { Have cranes, lifting machines and personnel capable } \\
\text { of working in height. }\end{array}$ & $\begin{array}{l}\text { Engineering units are equipped with } \\
\text { cranes, hoists, and their personnel are } \\
\text { capable of working in height. }\end{array}$ \\
\hline 14. & $\begin{array}{l}\text { The organization must have its own logistics, } \\
\text { medical and temporary accommodation conditions, } \\
\text { communications equipment and facilities. }\end{array}$ & $\begin{array}{l}\text { Military units have their own } \\
\text { communication, health and logistics } \\
\text { system, capable of providing self-care } \\
\text { and accommodation. }\end{array}$ \\
\hline 15. & $\begin{array}{l}\text { Have the ability to effectively support disaster } \\
\text { medicine tasks. }\end{array}$ & $\begin{array}{l}\text { Military health centers and temporary } \\
\text { field hospitals, laboratories are suitable } \\
\text { taking care of the injured. }\end{array}$ \\
\hline 16. & $\begin{array}{l}\text { Have temporary supply and accommodation } \\
\text { capabilities, which may be used in the interest of the } \\
\text { evacuated population. }\end{array}$ & $\begin{array}{l}\text { Military organizations have temporary } \\
\text { accommodation and catering materials, } \\
\text { equipment, water purification and camp } \\
\text { site building capabilities. }\end{array}$ \\
\hline
\end{tabular}

From the above, it is clear to see that military organizations have all the capabilities, assets and personnel that make them eligible to participate in disaster management tasks. They are the only organization that is capable of meeting all the requirements, fully or partially. With the disappearance of a bipolar world order, military reforms took place in the countries of the region, accompanied by a reduction in the personnel, and apart from a few exceptions, narrowing the maintenance costs of the armed forces. This has an inevitable impact on their disaster management tasks. The change of the security environment, however, has put the military forces back into focus. The increase in the number of disasters, the change in their nature and intensity, draws the attention to that one should anticipate cases that cannot be solved without military force. It is a great 
challenge for the military forces in every country, because they must be capable of, in addition to performing their basic duties (defending the country's sovereignty and territorial integrity), participating in disaster management as well.

\section{Conclusion}

The protection against disasters, nowadays, has become a global task, every country deems it supreme and strives to develop a complex system of protection against them. In the elimination of their consequences, in every country of Europe, military forces are involved as contributors. I have proven that disasters create complex incident sites in the built environment, and then, I have defined the basic elements whose damage or destruction is most likely to occur and I have described the characteristics of these being damaged. I have shown a relationship between the features of damages, the tasks to be done, as well as the personnel and assets needed. Based on this, I have defined the basic requirements of the tasks to be performed, and I have ascertained that military forces meet all the requirements of disaster management, fully or partially, through their existing capabilities.

The above findings support the conclusion that military forces are able to participate, with high efficiency, in the performance of their missions against disasters, so, that in the future, they must continue to maintain their capabilities and, if possible, even develop them.

\section{REFERENCES}

Antal, Ö. (2017). The Role of the Government in the Field of Public Protection in the Prevention of Earthquake Disasters, AARMS, 16(2), 67-82.

Bonnyai, T. (2014). Special tasks for professional disaster management bodies related to the identification, designation and protection of critical infrastructures in Hungary, AARMS, 13(4), 519-526.

Bundesamt für Bevölkerungsschutz. (2015). Umsetzung Strategie Bevölkerungsschutz 2015+: Auf dem Weg in die Zukunft, Bevölkerungsschutz, 9, 7-10.

Cabinet Office. (2012). National Risk Register of Civil Emergencies, available at: https://www.gov.uk/government/uploads/system/uploads/attachment_data/file/211858/CO_N ationalRiskRegister_2012_acc.pdf, accessed on: 16.01.2018.

EM-DAT The International Disaster Database. (2016). 2015 Disaster in numbers, available at: https://www.unisdr.org/files/47804_2015disastertrendsinfographic.pdf, accessed on: 14.12.2017.

General Inspectorate for Emergency Situations (GIES). (2016). Country report 5.1 Conditionality Romania 2016, available at: https://www.igsu.ro/documente/RO-RISK/ Raport_Final_de_tara.pdf, accessed on: 20.12.2017.

Hornyacsek, J. (2011). Systematic approach of the preparation of population in the frame of a changing defence scheme, Hadmérnök, VI(4), 81-93.

Hornyacsek, J. (2017). A mentési időszak feladatai és szerepe egy közösség katasztrófákkal szembeni rezílienciájának növelésében, Hadmérnök, 12: II. különszám, 25-48.

Kiss, B. (2015). Az ABV felderítés eszközei, különös tekintettel a pilóta nélküli légi jármüvekre, Sereg Szemle, XIII, 2-3, 33-40.

Magyarország Kormánya. (2012). 1035/2012. (II. 21.) Korm. határozat Magyarország Nemzeti Biztonsági Stratégiájáról, Budapest: Magyar Közlöny. 
Magyarország Kormánya. (2014). Jelentés Magyarország nemzeti katasztrófakockázatértékelési módszertanáról és annak eredményeiröl, available at: http://www.kormany.hu/ download/1/43/00000/tervezet.pdf, accessed on: 14.01.2018.

Ministry of National Defense (MoND). (2015). White Paper on Defense - Romania, 3rd Chapter, available at: http://english.mapn.ro/aboutmod/documents/carta_alba_apararii_en.pdf, accessed on: 04.01.2018.

Muhoray, Á. (2017). A polgári védelem helye a modern katasztrófavédelemben, Hadmérnök XII. 2, 188-200.

Norwegian Directorate for Civil Protection (DSB). (2014). National Risk Analysis 2014. available at: https://www.dsb.no/globalassets/dokumenter/rapporter/nrb_2014 english.pdf, accessed on: 26.01. 2018.

Padányi, J., \& Halász, L. (2012). A klímaváltozás hatásai, available at:http://archiv.uninke.hu/downloads/konyvtar/kovasz/padanyi_klimavaltoz_tanulm.pdf, accessed on:_10.12.2017.

Stiftung Wissenschaft und Politik (SWP) and German Marshall Fund of the United States (GMF). (2013). Neue Macht, neue Verantwortung. Berlin: Deutsches Institut für Internationale und Sicherheit.

Swedish Civil Contingencies Agency (MSB). (2012). Swedish National Risk Assessment 2012, available at: https://www.msb.se/RibData/Filer/pdf/26621.pdf, accessed on: 06.01.2018.

Szabó, S., \& Tóth, R. (2015). Adalékok a légierő Force Protection képességének növeléséhez, Repüléstudományi Közlemények, XXVII. 1, 121-139.

The Presidential Administration Romania. (2015). National Defense Strategy 20152019. Bucharest, available http://old.presidency.ro/static/National\%20\%20Defense\% 20Strategy\%202015\%20-\%202019.pdf, accessed on: 19.01.2018.

Tóth, A., \& Siposné Kecskeméthy, K. (2017): Magyarország legjelentősebb természeti katasztrófái - online katasztrófatérkép, Müszaki Katonai Közlöny, XXVII. évfolyam, 4, 148-169.

Varga, F. (2017). Az önkéntes közremüködés a katasztrófavédelemben, Védelem Tudomány II. Évfolyam 2, 199-208.

Wehrhaftes. (2017). Tag der Wehrpflicht - Wirtschaft und Landesverteidigung, available at: http://www.wehrhaftes-oesterreich.at/iv-tag-der-wehrpflicht wirtschaft-und landesverteidigung/, accessed on: 28.01.2018. 